\title{
Otoritas Guru Dalam Konteks Pendidikan Kritis di SMA Negeri Kota Padang
}

\author{
Isnarmi Moeis, Al Rafni, Junaidi Indrawadi \\ Fakultas Ilmu-IImu Sosial Universitas Negeri Padang
}

\begin{abstract}
Abstrak: Penelitian ini bertujuan untuk menggambarkan fenomena interaksi belajar mengajar di sekolah dengan sudut tinjauan pendidikan kritis. Subjek penelitian adalah guru-guru SMAN di Kota Padang yang terdiri dari guru PKN dan Sosiologi. Untuk setting penelitian dipilih 6 SMAN yaitu SMAN 1 dan SMAN 2 Padang mewakili sekolah unggul, SMAN 3 dan SMAN 5 mewakili sekolah pra unggul, dan SMAN 7 dengan SMAN 12 mewakili sekolah kategori biasa. Dari enam sekolah tersebut dipilih masing-masing 1 guru PKn dan 1 guru Sosiologi. Aspek yang diamati dalam penelitian ini adalah pola interaksi guru dan siswa dalam proses pembelajaran di kelas. Untuk menganalisis interaksi tersebut digunakan pendekatan Analisis Wacana Kritis dari Fairclough, khususnya mengenai kontrol Interaksi (Interactional Control Feature). Kerangka teori yang digunakan adalah teori otoritas dari John Wilson yang menyoroti penggunaan otoritas guru dalam kelas. Dari hasil pengamatan ini ditemukan bahwa interaksi guru siswa yang ada saat ini masih banyak didominasi oleh guru. Penggunaan otoritas guru masih terfokus pada pencapaian target berupa penguasaan materi seperti yang telah direncanakan, dan pada akhirnya dibuktikan melalui keberhasilan dalam menjawab soal tes (tengah semester atau akhir semester). Disimpulkan bahwa guru belum menggunakan otoritas yang diarahkan kepada pendidikan atau pemberdayaan siswa sebagai subjek belajar.
\end{abstract}

Kata Kunci: pendidikan kritis, critical discourse analysis, dan otoritas guru

\begin{abstract}
The aim of this research is to describe the phenomenon of learning interaction in terms of critical education in the State Senior High School in Padang. The subjects of this research are the teachers of Civics Education and Sociology. The research was held at six schools: SMAN 1 and SMAN 2 Padang represents the best school; SMAN 3 and SMAN 5 represents the good school, and SMAN 7 and SMAN 12 represents the ordinary school. These 6 school selected one PKn teacher from each school among the aspect observed in this research is the pattern of interaction between teachers and students in learning process at the classroom. To analyze this interaction was approached by Critical Discourse Analysis of Fairlclough, especially dealing with Interactional Control Feature. The theoretical framework was based on theory of teachers' authority by John Wilson. The result of this study shows that interaction between teachers and students is dominated by teachers. This authority tend to direct students on achieving the target of learning by mastering the material which proved by success on passing the test (mid of last term semester). In short, teachers have not applied their authorities yet on empowering students as the subjects of learning.
\end{abstract}

Key words: critical pedagogy, critical discourse analysis, and teachers authority.

\section{Pendahuluan}

Dari analisis konflik horizontal yang terjadi di Ambon, Poso, dan juga di Sambas, ditemukan salah satu penyebab berlarut-larutnya konflik karena tajamnya segregasi antarkelompok yang kemudian dimanfaatkan oleh orang tertentu untuk menimbulkan pertikaiaan (Moeis, 2006). Pola yang dilakukan oleh orang-orang yang menghendaki konflik berlangsung adalah dengan cara menyebarkan isu yang mengundang emosi masyarakat. Karena kuatnya ikatan kelompok maka anggota masyarakat kehilangan pertimbangan kritis dalam bertindak sehingga langsung melakukan reaksi balik terhadap kelompok yang dicurigai sebagai musuh kelompoknya. Secara teori fenomena konflik seperti ini disebut dengan ethnic entrepreneur. Dalam kondisi ini masyarakat menjadi kehilangan 
daya rasional dan berpikir sehat. Bila dilihat konflikkonflik horizontal lainnya, memiliki pola yang hampir sama dengan hal di atas.

Atas dasar ini, dari kacamata pendidikan dilihat bahwa perlu satu pendekatan pendidikan yang sejak dini membantu masyarakat menyadari adanya sistem berpikir yang salah dalam rangka membangun hubungan antarkelompok. Pendidikan ini disebut dengan pendidikan multicultural transformative . Ciri utama dari pendidikan transformatif adalah menggunakan pendekatan kritis, yang dilakukan untuk membangun kesadaran individu (self counciousness) dalam menghadapi tantangan dengan cara melakukan perubahan yang dimulai dari diri (selftransformation) dan sampai kepada perubahan lingkungan (social transformation). Dengan pendidikan kritis siswa diajak mengamati dan mencermati konsep-konsep berpikir yang dibangunnya serta faktor-faktor yang mempengaruhi konsep tersebut, untuk kemudian dilanjutkan dengan melakukan perubahan terhadap konsep-konsep berfikir yang tidak sesuai dengan tujuan pendidikan yang ditetapkan.

Untuk dapat menerapkan gagasan Pendidikan Multikultural Transformatif, diperlukan kajian yang mendalam tentang iklim sekolah yang akan menjadi latar belakang keberhasilan pelaksanaan pendidikan ini. Satu di antara faktor yang perlu diperhitungkan dalam latar tersebut adalah guru, khususnya otoritas guru. Dalam penelitian ini akan dikaji sejauh mana otoritas guru telah digunakan sebagai upaya pendidikan yang bersifat edukatif dalam membangun kesadaran siswa untuk melakukan perubahan. Penelitian ini bersifat penjelasan tentang gejala-gejala yang tampak mengenai penggunaan otoritas guru di dalam kelas. Penjelasan ini merupakan latar teoritis dan juga praktis bagi penerapan pendidikan multikultural transformatif. Dengan kata lain, temuan tentang fenomena penggunaan otoritas guru dalam mengajar saat ini, merupakan entry point bagi penerapan pendidikan multikultural transformatif di sekolah.

Secara umum permasalahan penelitian adalah menyangkut sejauh mana selama ini penggunaan otoritas guru telah mendukung terhadap konsep-konsep pendidikan kritis. Secara spesifik permasalahan penelitian itu dapat dirumuskan sebagai berikut: 1) Apakah guru telah memfasilitasi siswa belajar satu sama lain; 2) Apakah guru mendorong siswa memecahkan masalah dan mengambil keputusan; 3) Apakah guru memfasilitasi siswa untuk melihat satu permasalahan dari berbagai perspektif; 4) Apakah guru membantu perkembangan wawasan siswa melalui proses reflektif; 5) Apakah guru menempatkan dirinya sebagai partner siswa dalam proses menemukan pengetahuan.

Secara spsifik penelitian ini bertujuan untuk mengetahui bagaimana guru menggunakan otoritas di dalam kelas, apakah penggunaan itu telah mendukung pelaksanaan konsep-konsep pendidikan kritis, terutama dilihat dilihat dalam lima aspek: 1) cara guru memfasilitasi siswa satu sama lain dalam belajar; 2) cara guru mendorong siswa dalam memecahkan masalah dan mengambil keputusan; 3) cara guru memfasilitasi siswa melihat permasalahan dalam berbagai perspektif; 4) cara guru membantu perkembangan wawasan siswa melalui proses reflektif; 5) cara guru menempatkan dirinya sebagai partner siswa dalam belajar.

\section{Kajian Literatur}

Sebagaimana telah dikemukakan di atas bahwa pendidikan yang dapat menjawab tantangan ke depan bangsa Indonesia adalah Pendidikan Multikultural Transformatif. Inti dari Pendidikan Multikultural Transformatif menekankan perlunya penghargaan terhadap perbedaan dalam masyarakat, namun dikembangkan dalam kerangka Negara Kesatuan Republik Indonesia. Pandangan ini dikembangkan dalam 5 nilai pokok pendidikan multikultural transformatif, yaitu: 1) Ketaqwaan terhadap Tuhan Yang Maha Esa, 2) tanggung jawab terhadap negara kesatuan RI, 3) penghargaan, pengakuan, dan penerimaan keragaman budaya, 4) menjunjung tinggi supremasi hukum, dan 5) penghargaan martabat manusia dan hak asasi yang universal.

Karakteristik utama dari pendidikan transformatif adalah menggunakan pendekatan kritis, yaitu pendidikan ditujukan untuk membantu siswa mengembangkan keterampilan sosial dan pengambilan keputusan (Nieto, 1999). Guru dan siswa bersama dan saling belajar dalam memperoleh pengetahuan melalui proses reflektif, dan 
pengambilan keputusan. Guru dan siswa samasama menjadi subjek belajar. Pendidikan kritis merupakan lawan dari pendidikan yang menempatkan siswa sebagai objek yang menerima pengetahuan secara pasif (Freire, 1998). Karena itu, dalam pendidikan kritis guru tidak lagi sebagai penyampai pengetahuan yang dianggapnya benar, melainkan guru bersama siswa membangun pengetahuan (McLaren, 1998). Pendidikan kritis merupakan pendidikan transformasi diri guru dan juga siswa dalam ranah berpikir (thinking), merasa (feeling), dan bertindak (acting) (Howard, 1999). Dari semua karakteristik itu, ada implikasi bahwa guru perlu mengalihkan otoritasnya sebagai instruktur menjadi fasilitator yang ikut bersama-sama siswa melakukan transformasi diri dan lingkungannya (fasilitator-transformator).

Pada ekspositori otoritas guru lebih dominan dengan peran sebagai instruktur, tetapi dalam inkuiri hingga transformasi guru mengurangi otoritasnya dengan melibatkan siswa dan menempatkan dirinya sebagai fasilitator pembelajaran. Bahkan, pada transformasi guru melimpahkan sebagian otoritasnya dengan bersama-sama siswa melakukan proses perubahan diri dan lingkungan mereka .

Penelitian menunjukkan bahwa penggunaan otoritas guru sebagai fasilitator dalam pembelajaran sangat membantu pengembangan potensi siswa (Mateus Yurnamanto \& Rosalina Nugraheni: 2006; Akmal dan Jumiati, 2006). Berarti dari penelitian tersebut disimpulkan bahwa semakin bergerak pola penggunaan otoritas guru ke titik sebelah kanan maka dimungkinkan semakin luasnya pengembangan potensi siswa.

Pendidikan transformatif barakar pada filsafat pendidikan rekonstruksi sosial (social reconstructionist). Gagasan ini merekomendasikan guru dan sekolah, agar berangkat dari pengkajian kritis tentang budaya di tempat mereka berada. Mereka berusaha mengidentifikasi bidang-bidang yang mengandung kontroversi, konflik dan inkonsistensi, kemudian mengeksplorasi dan menemukan pemecahannya (Orsntein \& Levine, 1984: 206). Penganut rekonstruksinis meyakini bahwa pendidikan adalah sarana membuat perubahan. Perubahan dalam masyarakat dimulai dari pendidikan, dengan cara guru bersama siswa mengkaji secara kritis warisan budaya, menentang isu yang paling kontroversial, dan berkomitmen terhadap perubahan, merencanakan konstruksi hipotetik, dan membuat hubungan dengan program-program yang dirancang untuk membuat perubahan.

Dalam kaitan dengan otoritas guru maka melalui pendekatan kritis guru mengarahkan otoritasnya untuk menggugah kesadaran dirinya dan siswa melakukan perubahan.

Kajian otoritas guru dikembangkan dari pemikiran John Wilson yang melihat otoritas dalam hubungan pendidikan ada 4, yaitu otoritas praktis dan teoritis, serta otoritas de facto dan de jure. Otoritas praktis dan teoritis merupakan wewenang guru, sedangkan otoritas de facto dan de jure merupakan legitimasi wewenang tersebut (Steutel \& Spiecker, 2000). Dalam penelitian ini, otoritas yang jadi fokus perhatian adalah otoritas praktis dan teoritis yang berkaitan langsung dengan peran guru dalam membelajarkan siswa. Otoritas praktis berkenaan dengan tindakan guru seperti mendisiplin siswa, memberi hukuman, memberi instruksi dan mengarahkan siswa sedangkan otoritas teoritis berkenaan dengan beliefs yakni kerangka berpikir guru dalam membelajarkan siswa. Kerangka berpikir ini tercermin melalui pengetahuan dan keterampilan guru yang digunakan untuk membantu siswa menjadi subjek belajar bagi dirinya sendiri. Dengan kata lain, otoritas teoritis menunjukkan apakah guru meyakini pembelajaran adalah proses mendidik siswa menemukan informasi dan melakukan perubahan, atau sebaliknya pembelajaran adalah proses pemberian informasi. Keyakinan ini memberi gambaran bagaimana proses pembelajaran yang akan dilakukan oleh guru dan bagaimana guru melengkapi pengetahuan dan keterampilannya sesuai dengan keyakinan itu. Sejalan dengan pendapat Maslovaty (2000) yang menegaskan bahwa pengetahuan dan keterampilan guru merupakan faktor yang paling berpengaruh terhadap belajar siswa.

Dilihat dari segi hubungan otoritas dengan strategi pembelajaran, Bingham (2002) mengungkapkan bahwa pembelajaran yang memberi tahu siswa tentang informasi menunjuk-kan penggunaan otoritas yang sepenuhnya di tangan guru dan tidak bersifat mendidik, jika dibandingkan 
dengan pembelajaran yang mengajukan pertanyaan untuk memandu siswa berpikir dan menemukan informasi menunjukkan penurunan otoritas ke arah proses pendidikan siswa. Dalam hal ini, Bingham tampaknya mengungkapkan bahwa keterampilan guru bertanya merupakan faktor penting yang menentukan apakah proses pembelajaran itu mendidik siswa atau memberi tahu siswa. Bila dikaitkan pendapat Bingham dengan otoritas teoritis dan praktis dari Wilson, tampaknya otoritas yang dimaksud oleh Bingham adalah otoritas praktis. Artinya, bila otoritas praktis lebih menonjol dalam pembelajaran maka ada kecenderungan guru tidak bersifat mendidik.

Oleh karena itu, untuk melakukan pendidikan transformatif diperlukan kemauan dan kemampuan guru untuk mengalihkan otoritas yang bersifat mengarahkan siswa menjadi otoritas yang bersifat memfasilitasi perubahan dalam diri siswa. Upaya ini hanya tercermin dalam pendekatan pembelajaran yang bersifat kritis, yaitu memberdayakan siswa dalam proses pencerahan diri mereka; melepaskan siswa dari posisi objek yang pasif menjadi subjek yang aktif dalam belajar (Moeis, 2001).

\section{Metodologi Penelitian}

Penelitian ini dikembangkan berdasarkan pendekatan kualitatif, dengan menggunakan tradisi "grounded theory". Menurut Creswell (1998: 86) tradisi ini menekankan pada upaya perumusan analisis abstrak tentang suatu fenomena yang berhubungan dengan suatu situasi khusus. Dalam hal ini, target yang diharapkan dalam penelitian adalah penggambaran secara kualitatif penggunaan otoritas guru dalam interaksi belajar dari sudut pandang pendidikan kritis.

Data penelitian berupa transkrip yang diambil dari wacana proses belajar mengajar di dalam kelas. Sumber data adalah semua partisipan dalam proses belajar (guru dan siswa). Data tersebut dianalisis dengan menggunakan pendekatan Analisis Wacana Kritis atau yang lebih dikenal dengan Critical Discourse Analysis (CDA) dari Fairclough (1995) khususnya mengenai analisis teks yang melihat bentuk-bentuk kontrol interaksi atau Interactional Control Features (ICF)

Berdasarkan unsur-unsur dalam ICF, proses interaksi belajar mengajar diamati dalam 5 aspek, yaitu: 1) pola pengaturan giliran partisipan dalam proses belajar (hak dan kewajiban partisipan; simetris atau tidak simetris); 2) pergantian struktur dalam proses belajar (pengaturan siklus pertanyaan-respon-asesment dalam proses belajar mengajar); 3) pengontrolan topik dalam proses belajar (mekanisme menetapkan topik pembicaraan); 4) penetapan dan pengaturan agenda pembelajaran (evaluasi sistematik terhadap ungkapan yang diberikan guru); dan 5) formulasi perumusan hasil belajar (bentuk yang dipilih untuk merumuskan hasil belajar).

Kelima aspek di atas dilihat dalam kontinum dari titik sebelah kiri sebagai praktik belajar mengajar yang didominasi oleh guru hingga ke titik sebelah kanan sebagai praktik belajar mengajar yang memberi kesempatan yang luas kepada siswa. Kelima permasalahan yang diajukan di muka dijawab melalui indikator unteraksi tersebut.

Setting penelitian adalah SMAN Kota Padang, yang diwakili oleh enam sekolah, yang terdiri dari 2 sekolah kategori unggul, 2 sekolah kategori praunggul, dan 2 sekolah kategori biasa. Dari setiap sekolah diambil 2 orang guru pada mata pelajaran Pendidikan Kewarganegaraan (PKn) dan Sosiologi. Pertimbangan utama mengambil kedua mata pelajaran ini adalah besarnya peluang pada kedua mata pelajaran ini mengembangkan sikap multikulturalisme. Waktu penelitian dilalukan pada bulan Juli sampai dengan September tahun ajaran 2008.

\section{Hasil Penelitian dan Pembahasan}

\section{Setting penelitian}

SMAN yang terpilih dalam penelitian ini adalah SMAN 1 dan 2, SMAN 3 dan 5, dan SMAN 7 dan 12 di Kota Padang. Guru yang terlibat dalam penelitian ini 6 orang guru PKn dan 6 Guru Sosiologi. Satu orang guru berpendidikan S2, dan lainnya pendidikan $\mathrm{S} 1$, dengan pengalaman belajar berkisar antara 11 tahun sampai 28 tahun.

\section{Deskripsi Hasil Penelitian}

Berdasarkan indikator interaksi yang dikemukakan pada bagian metodologi maka deskripsi ini akan dikembangkan sebagai berikut: a) Pengaturan Giliran Partisipan, Dalam aspek ini ditemukan ada tiga pola interaksi yang terjadi dalam pem- 
belajaran yaitu: 1) Guru mengambil giliran berbicara di awal kemudian mengajukan pertanyaan, dan berlangsung terus sampai ke akhir pembelajaran. Pola interaksi dengan bentuk seperti ini ditemukan pada 7 guru dari 12 guru yang diamati dalam penelitian ini; 2) Guru mengambil peran berpartisipasi di awal pembelajaran, dilanjutkan siswa berpartisipasi, kemudian guru mengambil peran di akhir pembelajaran. Pola ini ditemukan dari 4 orang guru; 3) Guru mengambil peran di awal, dilanjutkan oleh siswa, guru bersama siswa mengambil peran bersama, dan ditutup dengan guru mengambil peran dan membuka peluang bagi siswa lain. Pola ini ditemukan pada 1 orang guru; b) Sesuai dengan lima permasalahan yang diajukan dalam penelitian ini, yaitu apakah ketiga pola pengaturan giliran tersebut memberi peluang terhadap 1) pembelajaran siswa satu sama lain; 2) siswa memecahkan masalah dan mengambil keputusan; 3) melihat permasalahan dari berbagai perspektif; 4) bagi siswa berfikir reflektif; dan 5) menempatkan guru sebagai partner siswa. Dari penelitian ini terlihat bahwa pola pertama tidak satu pun memperlihatkan peluang bagi kelima pertanyaan itu. Pola 2 hanya memberi peluang bagi siswa untuk belajar satu sama lain, tetapi tidak memberi peluang pada empat pertanyaan lainnya. Pola 3 memberi peluang hanya pada pertanyaan membelajarkan siswa dan membantu siswa memecahkan masalah; c) Pergantian Struktur, dilihat dari pergantian struktur, juga ada 3 pola interaksi yang ditemukan dalam proses pembelajaran sebagai berikut: 1) Guru mengajukan pertanyaan tertutup siswa menjawab (kadang individual kadang bersama-sama) kemudian ditutup dengan penjelasan guru; Pola 1 bagian $b$ ini ditemukan pada 7 interaksi belajar mengajar dari 12 orang guru yang diamati; 2) Guru mengajukan pertanyaan dengan cara memberi tugas (berdiskusi atau melakukan observasi), siswa mengerjakan tugas dan melaporkan hasil diskusi atau pengamatan di kelas, terakhir guru mengomentari atau memberi penjelasan lebih jauh sebagai upaya pemantapan atau menyimpulkan. Pola ini ditemukan pada 2 orang guru; 3) Guru mengajukan pertanyaan atau permasalahan untuk dikerjakan siswa, siswa mengerjakan diskusi atau menyusun makalah kemudian membacakan di kelas, terakhir guru membahas hasil diskusi bersama-sama dengan siswa dan menyimpulkannya. Pola 3 ini ditemukan pada 3 orang guru.

Sama halnya dengan indikator interaksi sebelumnya, pada indikator pergantian struktur terlihat bahwa pola 1 tidak memberi peluang bagi membelajarkan siswa, memecahkan masalah dan mengambil keputusan, melihat masalah dari berbagai perspektif, mendorong siswa berpikir reflektif, dan menempatkan diri sebagai partner. Pada pola 2 hanya memberi peluang dalam membelajarkan siswa satu sama lain. Pola 3 hanya memberi peluang dalam membelajarkan siswa satu sama lain dan memecahkan masalah; d) Pengontrolan topic, dari seluruh interaksi belajar mengajar kedua belas guru yang diamati, diperoleh bahwa semua pengontrolan interaksi didominasi oleh guru. Meskipun ada pada bagian tertentu siswa berpartisipasi, tetapi guru selalu memberi arahan agar pembicaraan tetap berada dijalur yang dikehendaki guru. Dari pola ini terlihat bahwa tidak satu pun yang sesuai dengan pertanyaan penelitian; e) Pengaturan agenda, biasanya penetapan agenda pembelajaran ditetapkan di awal pembelajaran oleh guru. Caranya adalah dengan menyampaikan topik dan juga standar kompetensi yang diharapkan akan dicapai dalam pembelajaran. Namun, sepanjang interaksi berlangsung guru juga melakukan pengaturan agenda dengan cara tertentu. Dalam hal ini yang dilihat adalah bagaimana cara guru merespon setiap pembicaraan yang berasal dari siswa. Apakah dengan cara ini guru membuka peluang bagi siswa untuk terlibat sebagai subjek belajar atau justru membatasi gerak siswa hanya sebagai objek.

Dari interaksi yang diamati dalam penelitian ini terlihat bahwa: 1) guru langsung merespon dengan cara mengomentari jawaban siswa sekaligus membetulkan dan menambah penjelasan tentang jawaban. Ada 8 guru yang menggunakan pola ini; 2) guru merespon jawaban siswa dengan pertanyaan lanjut (probing question), tetapi kemudian pada ujungnya guru memberi penjelasan. Pada pola ini ada sedikit peluang guru mengajak siswa berfikir lebih luas dari sekedar penguasaan materi; 3) Dari kedua pola ini, pola 1 sama sekali tidak memberi peluang kepada siswa seperti yang diajukan dalam 
pertanyaan penelitian. Hanya pola kedua yang memberi peluang bagi 2 hal dari 5 pertanyaan penelitian, yaitu memberi peluang bagi membelajarkan siswa dan memecahkan masalah serta mengambil keputusan; dan 4) Pengambilan simpulan.

Dalam aspek ini semua guru yang diamati mengambil peran dalam mengambil simpulan. Tampaknya bahwa semua proses pembelajaran baik yang melibatkan siswa atau tidak, berujung pada satu simpulan yang ditetapkan guru. Seperti halnya dengan aspek pengontrolan topik yang didominasi guru maka pada aspek ini juga tidak satu pun sesuai dengan lima pertanyaan yang diajukan dalam penelitian ini.

\section{Pembahasan}

Penerapan Kurikulum KTSP yang saat ini dipakai di sekolah, sesungguhnya merupakan peluang baik bagi guru untuk mengubah pola pembelajaran yang terpusat sepenuhnya kepada guru dan berorientasi pada tujuan. Dalam kurikulum sekarang guru memang diarahkan untuk melihat standar kompetensi sebagai pedoman dalam menetapkan rencana pembelajaran, tetapi proses pembelajaran itu sendiri diharapkan melibatkan siswa, sehingga siswa berperan sebagai subjek yang aktif dalam pembelajaran dan pembelajaran bermanfaat bagi pemberdayaan siswa.

Upaya guru untuk merespon keinginan KTSP sudah mulai tampak dalam proses pembelajaran dan kebutuhan guru-guru untuk meningkatkan kemampuan profesional mereka melalui kelompokkelompok kerja guru bidang studi yang telah teroganisir rapi. Dari wawancara dengan guruguru, mereka menyatakan bahwa kebanyakan mereka mendapat manfaat dari KKG ini mengenai metode pembelajaran yang lebih bervariasi (Wawancara dengan salah seorang guru sosiologi, 5 Juni 2008). Di samping itu guru-guru juga merasakan bahwa pola pembelajaran lama yang terpusat pada guru tidak relevan lagi, sehingga ada keinginan sebagian besar guru untuk mendapat pencerahan melalui pelatihan atau pendidikan lanjut, bahkan guru dengan jujur menyatakan kepada peneliti pada bagian mana proses yang mereka laksanakan mesti diperbaiki lagi dan minta diberi masukan (disimpulkan dari pembicaraaan yang dilakukan setelah pengamat- an terhadap proses belajar di dalam kelas).

Di sisi lain, guru belum dapat sepenuhnya beranjak ke pola pembelajaran yang baru bahkan pada sekolah yang tergolong unggul pun, di mana siswa sebagian besar memiliki kemampuan belajar yang tinggi dan potensial independen, masih cenderung guru mendominasi pembelajaran, terutama dalam pengontrolan topik-topik dan pengambilan simpulan. Apalagi pada sekolah kategori di bawah unggul yang guru sendiri merasakan bahwa siswa mereka sangat pasif dan berasal dari kelompok-kelompok ekonomi lemah semakin guru berkeyakinan betapa sulit untuk beralih ke pembelajaran yang lebih membuka peluang bagi siswa untuk belajar secara inkuiri atau discoveri, apalagi belajar dengan transformatif seperti yang ditargetkan dalam penelitian ini.

Ditinjau dari teori otoritas, tampak bahwa dalam fenomena pembelajaran (Sosiologi dan PKn) di SMAN yang diteliti ini guru mulai merasa tertantang untuk meningkatkan otoritasnya (teoritis) terutama yang menyangkut pengetahuan dan keterampilan dalam mengajar yang bersifat mendidik atau memberdayakan siswa. Di lain pihak, guru belum dapat melepaskan otoritas (praktis) sepenuhnya sehingga guru cenderung mengambil peran dominan dengan mengkondisikan pembelajaran agar tidak lepas dari target penguasaan materi yang direncanakan berdasarkan kurikulum. Dominasi peran ini tampak dalam pengontrolan topik, penetapan agenda, dan pengambilan simpulan.

Untuk dapat menjelaskan fenomena penggunaan otoritas guru sebagaimana maksud penelitian ini, terlebih dahulu akan dikemukakan suatu kerangka berpikir yang dijadikan peta untuk menentukan posisi dari pola interaksi (penggunaan otoritas guru) yang berlangsung saat ini di sekolah. Ringkasnya gambaran ini dapat dibaca dalam bagan 1 .

Bagan 1 menunjukkan bahwa semakin guru mengurangi perannya sebagai inisiator atau intruktur atau mengurangi pembelajaran yang bersifat ekspositori yang terpusat pada guru maka semakin besar kemungkinan guru mendekati peran sebagai mediator dan fasilitator atau bahkan sebagai partner siswa dalam belajar untuk sama-sama melakukan proses transformasi 


\begin{tabular}{|l|l|l|}
\hline Ekspositori & Inkuiri $\rightarrow$ diskoveri & tranformasi \\
\hline Instruktur & Fasilitator & partners siswa \\
\hline Guru sebagai inisiator & Guru sebagai mediator & $\begin{array}{l}\text { Guru sebagai } \\
\text { transformator }\end{array}$ \\
\hline $\begin{array}{l}\text { Terpusat pada guru } \\
\text { Peran Gqur }\end{array}$ & Terpusat pada siswa & Guru bersama siswa \\
\hline
\end{tabular}

Bagan 1. Peta Interaksi guru dalam kelas

diri mengubah kebiasaan-kebiasaan lama dalam aspek pengetahuan, sikap dan bahkan keahlian yang tidak kondusif bagi perubahan dalam masyarakat.

Melalui bagan 1 dapat dinyatakan bahwa pada kolom kiri guru lebih cenderung menggunakan otoritas praktis dengan sangat ketat yaitu mengarahkan siswa kepada pencapaian target pembelajaran yang kaku berupa penguasaan materi pembelajaran yang sejalan dengan tuntutan kurikulum. Menurut Bingham seperti yang dikemukakan sebelumnya, proses ini cenderung tidak mendidik atau bahasa lain tidak memberdayakan siswa. Semakin ke kanan, guru melonggarkan penggunaan otoritas praktis yang kaku dan ketat, dengan cara memfasilitasi belajar siswa sesuai kemampuan dan potensinya dan tidak diikat pada keinginan guru yang sudah ditetapkan sebelumnya.

Adapun kondisi proses atau interaksi pembelajaran yang terekam dalam penelitian ini menunjukkan bahwa hampir semua guru sedang bergerak meninggalkan peran sebagai inisiator dan instruktur penuh, tetapi gerak perubahan itu belum mencapai titik menempatkan diri sebagai mediator atau fasilitator pembelajaran. Guru masih terpaku dengan penggunaan otoritas praktis yang mengutamakan pembelajaran pada penguasaan materi, daripada pembelajaran yang bersifat mendidik atau memberdayakan siswa. Dalam mengembangkan pembelajaran guru berpatokan sangat ketat kepada standar kompetensi yang sudah ditetapkan, sehingga semua tindakan pembelajaran meskipun dengan melibatkan siswa tetap dalam kerangka kepentingan guru untuk mencapai target penguasaan materi yang ditetapkan dalam rencana pembelajaran yang diturunkan dari kurikulum.

Jika inkuri atau diskoveri sebagaimana digambarkan pada bagan 1 berada pada titik tengah, belum tercapai oleh kondisi interaksi guru siswa saat ini maka pembelajaran transformatif yang posisi lebih lebih ke ujung kanan masih jauh dari jangkauan kenyataan. Dengan kata lain, penggunaan otoritas guru dalam pembelajaran di sekolah saat ini belum ditujukan untuk hal-hal bersifat mendidik siswa dengan berbagai keterampilan seperti berpikir, memecahkan masalah, dan mengambil keputusan, tetapi guru

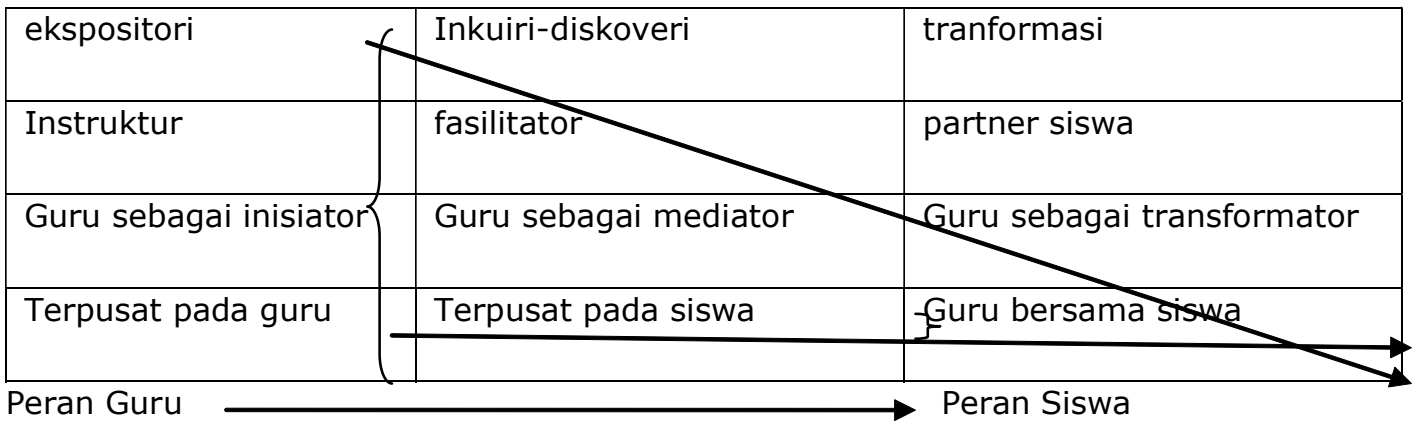

Bagan 2. Interaksi Guru Siswa Saat ini di Sekolah 
lebih mengutamakan penggunaan otoritas tersebut untuk membantu siswa menguasai materi pembelajaran melalui arahan yang ketat dari guru. Jadi dalam pembelajaran guru lebih mengutamakan otoritas praktis.

Jika digambarkan dalam bagan maka gambaran pembelajaran yang ada sekarang dapat disimpulkan kebalikan dari bagan tersebut:

Bila diamati lebih jauh fenomena pembelajaran yang tergambar seperti pada bagan 2 , timbul pertanyaan mengapa guru terlihat sulit berubah dari posisi sebagai instruktur menuju posisi fasilitator atau transformator. Memang untuk menjawab secara akurat kemengapaan ini memerlukan penelitian lanjut, tetapi secara implisit terlihat bahwa tingkat pendidikan dan pengalaman guru cukup berpengaruh pada cara mengajar dan orientasi berfikir guru. Pada umumnya pola interaksi guru yang mengarah pada pemberian kesempatan kepada siswa, dilakukan oleh guru-guru yang memiliki pendidikan lanjut dan berpengalaman luas dalam pembelajaran.

\section{Simpulan dan Saran}

\section{Simpulan}

Dari hasil penelitian ini dapat disimpulkan sebagai berikut. Interaksi guru dan siswa dalam pembelajaran cendrung didominasi oleh guru, pada beberapa proses guru sudah memberikan kesempatan siswa untuk belajar seperti memberikan kesempatan berdiskusi (panel dalam kelas), atau memberikan kesempatan berfikir atau menjawab pertanyaan-pertanyaan guru. Otoritas guru masih tinggi sebagai subjek yang menentukan target pencapaian hasil belajar bila dilihat dari penguasaan materi pembelajaran. Pemberian kesempatan kepada siswa hanya sekedar variasi pembelajaran, sementara otoritas pengontrolan topik dan pengambilan kesimpulan hasil belajar ada pada guru. Hanya saja dalam pembelajaran guru sukses memfasilitasi siswa dalam mengontrol dan penyimpulan pelajaran.

\section{Saran}

Sesuai dengan temuan dan simpulan penelitian, maka disarankan: pertama, mengadakan pelatihan dan pendidikan bagi guru untuk mengenali lebih jauh pembelajaran yang bersifat diskoveri dan transformative. Kedua, perlu dilakukan pengkajian yang lebih mendalam tentang kerangka berfikir guru dalam pembelajaran terutama dalam kontek pendidikan kritis. Ketiga, perlu dilakukan penelitian lebih lanjut terutama tentang upaya guru dalam membantu perkembangan wawasan siswa melalui proses reflektif dan sekaligus memotivasi siswa untuk melihat permasahan dari berbagai perspektif.

\section{Pustaka Acuan}

Akmal \& Jumiati. 2006. Upaya Peningkatan Kualitas Perkuliahan HAM melalui Metode Komunikasi Reflektif Pada Mahasiswa Pendidikan Kewarganegaraan FIS UNP, Hasil Penelitian sedang dalam proses publikasi, Program Studi ISP_FIS Universitas Negeri Padang.

Bingham, Charles. 2002. Authority and Educational Questioning. Ohio Valley Philosophy of Education Society. Dapat diakses pada www.ovpes.or/2002/(13/09/2008).

Creswell, John. 1998. Qualitative Inquiry and Research Design: Choosing Among Five Traditions. Thousand Oaks, California: SAGE Publications.

Fairclough, Norman. 1995. Critical Discourse Analysis. London \& New York: Longman.

Freire, Paulo. 1998. The Paulo Freire Readers. Edited by Freire, Ana Maria \& Macedo, Donaldo. New York: Continuum International Publication.

Howard, Gary. 1999. We Can't Teach What We Don't Know: White Teachers, Multiracial Schools. New York: Teachers College, Columbia University.

Maslovaty, Nava. 2000. Teachers"Choice of Teaching Strategies for Dealing with Socio-Moral Dilemmas in the Elementary School, Journal of Moral Education Vol 29 Number 4 December 2000. p 429-445.

Mc Laren, Peter. 1998. Life in Schools : An Introduction to Critical Pedagogy. In the Foundation of Education. New York: Peter Lang. 
Mateus Yurnamanto \& Rosalina Nugraheni Purnami. 2006. "Analisis Wacana Proses Belajar Mengajar Bahasa Inggris dalam Kelas Berbasis Kompetensi" www.lppm.wima.ace.id. (13 Maret 2007).

Moeis, Isnarmi. 2001. Critical and Democratic Pedagogy. Paper Under the Institutional Linkage Project of University Negeri Padang and Indiana State University, USA periode 2000-2005.

Moeis, Isnarmi. 2006. "Kerangka Konseptual Pendidikan Multikultural Transformatif Berdasarkan Pola Hubungan Konflik Antar Etnik" Disertasi Universitas Pendidikan Indonesia, Bandung.

Nieto, Sonia. 1999. The Light in Their Eyes: Creating Multicultural Learning Communities. New York: Teacher College, Columbia University.

Ornstein, Allan \& Levine, Daniel. 1984. An Introduction to Foundations of Education. New Jersey: Houghton Mifflin Company.

Steutel, Jan \& Spiecker, Ben. 2000. "Authority in Educational Relationship" Journal of Moral Education, Vol 29 Number 3 September 2000. p 429-444. 